Zlatko Lagumdžija ${ }^{1}$

Lamija Krndžija²

Lejla Turulja ${ }^{3}$

\title{
INNOVATION IN PUBLIC SECTOR INSTITUTIONS IN THE FEDERATION OF BOSNIA AND HERZEGOVINA
}

\begin{abstract}
Innovation has become a necessity in order to overcome some challenging times in the rapid changing world. The world's paradigm is shifting towards sustainable development and shared values. Even though numerous benefits of innovating the public sector (PS) have been recognised worldwide, the concept of public sector innovation (PSI) is still new for Bosnia and Herzegovina. The complex and stratified structure of the Federation of Bosnia and Herzegovina (FBiH) and its PS has been forever standing in the way of any larger progress. The purpose of this paper is to contribute to the development of PSI in FBiH as an opportunity to enhance the performance of public services, increase their efficiency, and decrease the costs.

The research was completed by using a mixed-method approach in order to analyse the concept of innovation in the PS. The primary data was collected through semi-structured interviews with the management and a survey with close-ended questions which was completed by the employees of the public sector institutions in FBiH. The method of structural equation modelling was used in order to test the research hypotheses.

A part of this paper is analysing the main PSI drivers and challenges. The results show that the main obstacles to PSI are the institutional system and the regulations in the FBiH. On the other side, the manager and employees are considered to be the largest drivers of public sector innovation in FBiH. The paper concludes with several recommendations on how to overcome the main barriers of public sector innovation in $\mathrm{FBiH}$.
\end{abstract}

Keywords: Innovation management, $R \& D$, Innovation incentives, e-Government, Institutional culture.

JEL: O38, O32, O31, H11, H41

1 Full Professor, School of Economics and Business, University of Sarajevo, Trg oslobođenja - Alija Izetbegović 1, Sarajevo

2 MA Public Sector Management, School of Economics and Business, University of Sarajevo, Trg oslobođenja - Alija Izetbegović 1, Sarajevo

3 Assistant Professor, School of Economics and Business, University of Sarajevo, Trg oslobođenja Alija Izetbegović 1, Sarajevo 


\section{INTRODUCTION}

Organizational innovation is the mechanism by which organizations identify new opportunities for enhancing their performance through the use of existing knowledge, the search for new knowledge and audits (Choi \& Chandler, 2015). Organizational innovation is one of the most significant capabilities of the 21st century (Hurley \& Hult, 1998)we address three research questions: (1. However, some authors point out that there is a difference between the private and public sectors when it comes to innovation. While in the private sector, innovation must only be profitable to pay off, in the public sector (PS) innovation must work to make something worthwhile (Coveney, 2008). In other words, innovation in the public sector involves more than simply doing a good job in public business and incorporating the broader public good. Public sector institutions have started actively working on the development of good governance and the improvement of their services (Keping, 2018). Numerous benefits of innovating the public sector have been recognised, and appropriate measures have been taken. Keping (2018) underlines, it is certain that the future of any efficient public sector will depend on innovation.

This paper aims to deepen knowledge and understanding on public sector innovation (PSI) in the current literature and to investigate the activities, challenges, and possibilities for the innovative public sector environment in the developing economy context. Many people, especially in the developing countries, have a defensive attitude toward innovation as to something just technologically based, hardly reachable and only available to scientists. The Organization for Economic Cooperation and Development (2017), claims that employees are the core of the PSI, and it is their dedication, which drives the innovation process. Hence, this paper will offer an analysis of the determinants of innovative public sector employee behaviour and provide an understanding of employee-level innovativeness.

\section{Literature Review}

People consider innovation as something revolutionary and believe that it must result in a cure for cancer or going to Mars. Certainly, this is also an innovation, but, as Thornton (2012) explains, innovation is happening all around us and every day at home or work. Innovation is a game-changer, meaning that some change happened compared to the previous state (Lewis, Ricard and Klijn, 2018). When it comes to innovation, it is important to understand the borderline between the public and the private sector (Koch and Hauknes, 2005). This includes the features of a product, the ownership and its control, financing, features of the competition, and the social benefits. These criteria combined result in the public governance concept. Koch and Hauknes (2005) underline that their non-excludability and non-rivalry characterise the goods in the public sector. 
Moreover, Bailey (2002) defines the PS as a set of government activities and its institutions. The public sector is frequently seen as the provider of non-market services that are established solely through collective democratic processes and according to citizen needs (Bailey, 2002). The public sector is mostly related to bureaucratic silos, followed by passivity and delays. Therefore, the main criticisms for the public sector are regarding its slow dynamics and absence of innovativeness. Sørensen and Torfing (2011) claim that an improvement can be achieved through privatization, deregulation, and the application of private sector planning principles. Regardless of this risk-averse culture in the public sector, their quality and the content of the policies five decades ago and today experienced some impressive transformations. The public sector is gradually shifting toward the provision of intangible services, which is demanding more innovation in public services (Sørensen and Torfing, 2011). Furthermore, novel management methods are required in order to answer the range of public interest questions effectively. Bertucci (2005) emphasises that the lower and middle-level employees initiate most of the innovation in the PS and that innovation in that context is not an answer to crisis nor is it driven by some financial reward, but by recognition.

\subsection{Innovation in Public Sector Institutions}

Throughout the recent period, governments have identified the need for better answering the environmental and social challenges with innovation. Schot and Steinmueller (2018) claim that the issues as climate change, poverty or pollution, are now the innovation challenges and opportunities for the governments. The new technology development will increase labour productivity and affect economic growth. The public sector institutions can improve the life quality of the citizens and create stronger communities through innovation (Schot \& Steinmueller, 2018).

Factors that may influence an environmental development in which PS innovation takes place, as underlined by Taylor (2018), include excellent project management and leadership skills, partnerships and especially the engagement of the citizens and the politicians. According to Mongey (2013), it is up to the management to support innovation initiatives and develop a common, entrepreneurial vision all over the institution. The support and willingness of the whole management is a key for a successful implementation of the innovative institutional activities. As noted by Borins (2001), innovation in the PS is commonly viewed as appearing at the top and only later being implemented by the public servants. OECD (2017), claims on the other side, that people are the core of the PSI, and it is their dedication, which drives the innovation process. The research has suggested that innovative idea can come from the employee at any institutional level. Hence, PS institutions should aim to motiva- 
te, provide opportunities, and encourage their employees in innovating. Motivation is, in most cases, intrinsic, but it is also highly dependent on the working environment, whereas opportunity refers mostly to the provision of autonomy and resources (OECD, 2017).

Mongey (2013) suggests that one way to stimulate innovation is through rewards. Hence, it is the task of the management to provide motivational rewards to their employees. Unfortunately, in many public sector institutions, innovation is not rewarded, but rather are the failed attempts punished. However, the institutions are starting to change, and it is very important in this regard to choosing an adequate reward system, which matches the institutional innovativeness (Mongey, 2013).

The barriers to PSI are, in most circumstances, result from the difference in the nature of innovation and the nature of the public sector. Cinar, Trott and Simms (2019) explain that the identification of the innovation obstacles is a critical factor of success in the process. It was indicated that a common form of organisational barrier is associated with administration activities. In addition, the resistance or the absence of support, which in most cases happens due to the incertitude of the new organisational circumstances, is an important internal barrier. Additionally, the lack of crucial resources as money, the IT infrastructure, time, or even the inconsistency with the current values can influence the results of PSI (Cinar et al., 2019).

\section{Hypotheses development}

A review of the literature was conducted in order to identify the hypotheses relevant to the achievement of the objectives of this paper. Six indicators, innovation drivers, networking, encouragement, empowerment, employee information, and rewarding were used to analyse the employees' innovative behaviour. The definition of innovative behaviour was adopted from Kurz, Hüsig and Dowling (2018), as a deliberate creation, introduction, and implementation of helpful novel ideas or processes at work by an employee. Lewis et al., (2018) analysed innovation drivers and networking in a way in which they support or hinder the public sector innovation.

Furthermore, networking, as the frequency of collaboration and communication outside of the institution, has been recently gaining increasing attention and relevance in the PS. Booyens and Rogerson (2017) found that networking has a vital role in obtaining knowledge and improving the technological capacities of an institutional innovation process. Consequently, following Lewis et al., (2018), two hypotheses are proposed:

H1: Innovation drivers influence innovative behaviour in public sector institutions.

H2: Networking influences innovative behaviour in public sector institutions. 
Nusair, Ababneh, and Kyung Bae (2012) underline that PS institutions are forced to adopt a new form of leadership which motivates and encourages its employee's participation and their innovative behaviour through the appropriate institutional environment. Lewis et al., (2018) notice that leadership, the values and capabilities of the managers, can immensely impact change and innovation. Furthermore, Kurz et al., (2018) claim that encouragement contributes to a challenging and supportive working environment which offers the employee a sense of autonomy and control and increases their intrinsic motivation and their innovative behaviour.

Fernandez and Moldogaziev (2012) discovered that the employee empowerment in the PS could enhance the institutional performance by looking for new methods of altering some process errors. Nevertheless, Abukhait, Bani-Melhem and Zeffane (2019) explain that the results from the studies on the relationship between empowerment and innovative behaviour differ. Some findings indicate a positive relationship in which a delegation of authority fosters motivation and innovation. Other findings show an insignificant, negative relationship in which the employees get confused in front of an issue (Abukhait et al., 2019).

Employee information, as the complete process of data, knowledge, and learning, is according to Daglio, Gerson and Kitchen (2014) the essential element for the improvement of innovation. Furthermore, Abukhait et al., (2019) emphasise that knowledge sharing, as the timely availability of information, enhances innovative employee behaviour and fosters critical thinking. Finally, Francesc (2009) found that rewarding is a way to express recognition and enhance PSI. Kurz et al., (2018) found that in regard to rewards, the extrinsic motivation is often taken with reserves, as in most cases, the intrinsic motivation shows a positive relationship with innovative behaviour. Hence, following Fernandez and Moldogaziev (2012), we propose the below-stated hypotheses:

H3: Encouragement influences innovative behaviour in public sector institutions.

H4: Empowerment influences innovative behaviour in public sector institutions.

H5: Employee information influences innovative behaviour in public sector institutions.

H6: Rewarding influences innovative behaviour in public sector institutions. 
Figure 1: Conceptual model

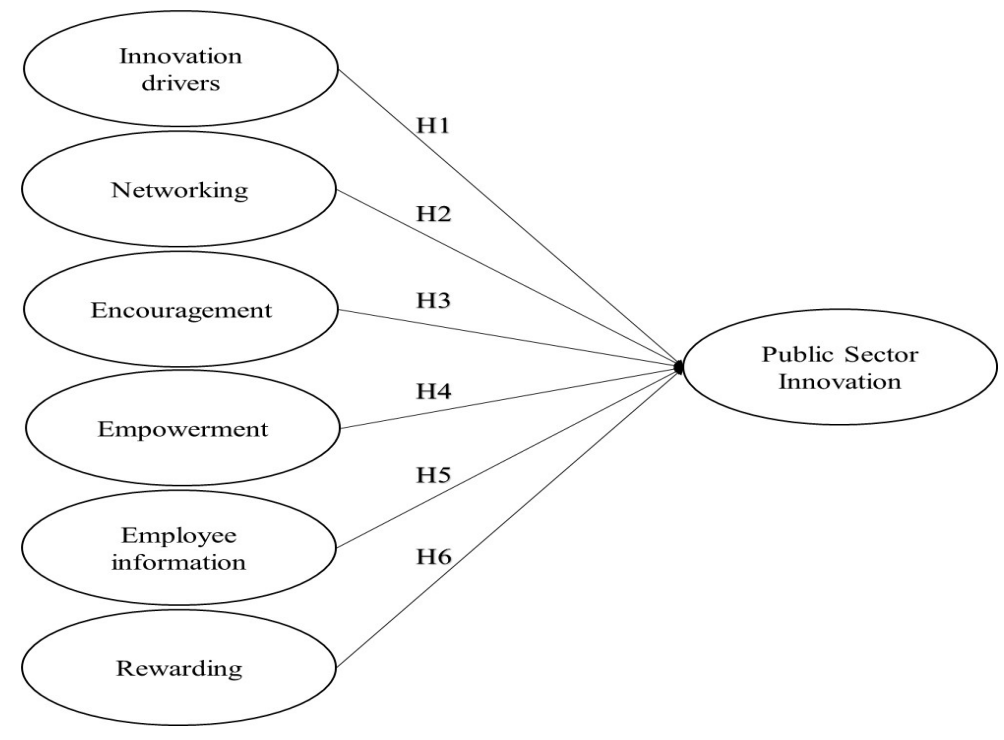

\section{Empirical Research}

The study refers to public institutions, and in order to understand the concept of PSI more comprehensively, it is necessary to consider the perception of operational and management levels of employees. Therefore, factors for employee level were measured quantitatively, while managers' perceptions were evaluated through a qualitative assessment. In that regard, the research methodology divided the research into quantitative and qualitative research, and the research focused on collecting and analysing both quantitative and qualitative data in the study in a sequential manner. In other words, a mixed-method approach, the methodology that helps using different methods for different purposes in the study and allows triangulation to take place at the level of result formulation (Ahuja, Yang, \& Shankar, 2009), was employed. The primary data was obtained through semi-structured interviews with the management of several identified PS institutions and a survey with close-ended questions was completed by the employees of the PS institutions in the Federation of Bosnia and Herzegovina (FBiH).

The total of 11 interviews were conducted in Sarajevo in the period from the 10th of July until the 25th July, 2019. During that period, nine public sector managers from eight institutions were interviewed, one University professor and one Policy specialist from an International Organisation. As some managers were not available for the interview, they sent a replacement or participated through the survey.

The population for the quantitative analysis consisted of all PS institutions in $\mathrm{FBiH}$, including 16 ministries, 2 agencies, and 11 institutes.

The survey was sent on the 17th of July 2019, through the Lime Survey Software and 
it was open until the 3rd August 2019. During that time 291 public sector employees completed and submitted the survey.

A semi-structured interview was conducted with the managers, while the operational level staff completed a questionnaire consisting of indicators of measurement models relevant to the proposed conceptual model. The questionnaire consisted of five parts with items reflecting the research variables. The measurement of indicators for innovation drivers and networking was adopted from Lewis et al., (2018), as well as a method for summation of the score. The measurement of indicators for encouragement was adopted from Coveney (2008), for the empowerment from Abukhait et al., (2019), for the employee information and innovative behaviour from Singh and Sarkar (2019), and for rewarding from Fernandez and Moldogaziev (2012). The control variables were age, education and job position. A total of 291 questionnaires were completed and submitted, representing the response rate of $16.18 \%$.

\section{Data Analysis and Results}

Data analysis is done through three basic steps:

- Analysis of qualitative data using NVivo 12 and following the procedure for open, axial and selective coding (Zsidisin, Melnyk, \& Ragatz, 2005) and presenting the results using a narrative synthesis approach (Wisdom, Ho, \& Chor, 2014).

- Quantitative data analysis using SPSS 22 and Lisrel 8.8 and confirmatory factor analysis (CFA), and structural equation modelling (SEM) (Hair, Black, Babin, \& Anderson, 2014).

- Triangulation of results by drawing conclusions to minimise bias (Kasabov, 2016).

\subsection{Qualitative data analysis}

The qualitative data which was obtained from the interviews were coded and analysed through NVivo 12 in nine categories. Some of the codes were barriers to innovation, drivers of innovation, methods of rewarding, institutional structure, manager's opinion on innovation, and others. The qualitative analysis showed that both the leader and employees are considered as the largest drivers of innovation. Most interviewees agreed that innovation in the public sector is foremost a bottom-up approach but only with the approval of the top management. This is a specific and important moment for public sector innovation when the energetic and moderately experienced employees meet a manager who is simply open to change and does not feel threatened by it.

The results showed that the innovative initiatives in the PS are mostly related to new documents, regulations, and laws which are suggested, improved, or created. Still, 
every interviewee recognised the institutional system and the regulations, as the largest challenges for public sector innovation. Besides these, the fact that politicians and managers are opposed to innovation and consider it as additional work, that the bureaucracy is so complex, and that the rewarding/ sanctioning system is almost non-existent, is making public sector innovation almost impossible. Almost half of the recommendations were related to the introduction of a proper rewarding system with a salary which is sensitive to good/ poor performance.

The interviewees described the institutional structure as primarily closed to innovation, static, outdated, and uninspiring, respectively to the frequency of answers. Every respondent confirmed that the public sector in $\mathrm{FBiH}$ is not innovative. The analysis also showed that the employees are primarily non-innovative due to their lack of knowledge. This can be related to the closed system, which is not stimulating any personal learning and skills development and in which the progress of some employees is considered as a threat. On the other side, it is interesting that intrinsic and personal satisfaction, as seeing the result or being recognised, have been shown as the greatest motivational factors.

\subsection{Quantitative data analysis}

Quantitative data analysis was conducted following recommendations of Hair et al., (2014). CFA was used to assess the reliability and validity of the measurement models. The structural model and the hypotheses were tested using SEM with ML estimation.

In the case of the innovation drivers and networking variables, a summated aggregate scale was used following Lewis et al., (2018). The measurement model for innovation drivers comprised of 12 items measuring perception of employees on the procedural and structural factors which either support or prevent PSI on a scale from 1 if mostly hinders to 5 if it mostly helps. Those items are annual budget, salary and promotion system, values and culture of the executive management, institutional structure, quality of ideas coming from the employees, values and culture of the politicians, quality of the policy proposals, national government pressure, EU directives, economic crisis, media attention, and citizen involvement (Lewis et al., 2018). The possible individual results on innovation drivers could range from 12 , in the case that every item hinders innovation, to 60 in the case that every item is supporting innovation from the point of view of the respondent. This summation of all 12 items gave the overall result of how supporting are the institutional procedures and structures in the public sector when it comes to innovation. The mid-point of the maximum score was 30, and as on the average, the total score per respondent or the sum of all means was 36.06 it can be concluded that in general, PS employees see these factors as slightly supporting innovation and not hindering it.

The measurement model for networking was adopted from Lewis et al., (2018). This was including all the forms of communication except the circulating emails and co- 
uld range from 1 if never to 5 if on a daily basis. Items of networking are an officer from another federal institution, a politician, an officer from the region, an EU officer, a representative of a business association, a leader of a medium or large private company, a representative of a citizens' group, a union representative, a media representative (Lewis et al., 2018). The possible individual scores on networking could range from 9 , in the case that there is no communication at all, to 45 in the case that respondents daily communicate with all the items from the list. This summation of all 9 items gave the overall picture on the extent of communication and networking in the public sector of the FBiH. The mid-point of the maximum score was 30, and as the average total score per respondent or the sum of all means was 22.5 it can be concluded that in general, PS employees rarely or even never communicate with each other.

Table 1: CFA Results for Measure

\begin{tabular}{|c|c|c|c|c|}
\hline Variable & Code & Indicator & $\begin{array}{l}\text { St. } \\
\text { loadings }\end{array}$ & t-value \\
\hline & ENCO1 & $\begin{array}{l}\text { Employees in my institution are encouraged to develop new } \\
\text { ideas }\end{array}$ & 0.813 & \\
\hline \multirow[t]{3}{*}{ Encouragement } & $\mathrm{ENCO} 2$ & Creative work is appreciated and recognised in my institution & 0.923 & 16.684 \\
\hline & ENCO3 & $\begin{array}{l}\text { People get fair and constructive feedback in regard to their new } \\
\text { ideas }\end{array}$ & 0.932 & 16.871 \\
\hline & ENCO4 & $\begin{array}{l}\text { We, the employees know what goals our } \\
\text { nstitution wants to achieve }\end{array}$ & 0.758 & 12.547 \\
\hline \multirow{4}{*}{ Empowerment } & EMP2 & $\begin{array}{l}\text { I am satisfied with my involvement in } \\
\text { the decisions which influence my work }\end{array}$ & 0.677 & \\
\hline & EMP10 & $\begin{array}{l}\text { I am authorised to make the required decisions in order to do } \\
\text { my job well }\end{array}$ & 0.802 & 10.202 \\
\hline & EMP11 & $\begin{array}{l}\text { My manager allows and trusts me to make the right decisions } \\
\text { on work. }\end{array}$ & 0.855 & 10.693 \\
\hline & EMP12 & $\begin{array}{l}\text { I have the opportunities for freedom } \\
\text { and independence in doing my job. }\end{array}$ & 0.853 & 10.674 \\
\hline \multirow{5}{*}{$\begin{array}{l}\text { Employee } \\
\text { information/ } \\
\text { Knowledge } \\
\text { sharing }\end{array}$} & KNOW3 & I regularly inform my colleagues about what I am working on & 0.763 & 8.841 \\
\hline & KNOW4 & $\begin{array}{l}\text { When I learn something I make sure my colleagues find out } \\
\text { about it }\end{array}$ & 0.852 & 9.495 \\
\hline & KNOW5 & I share new information with my colleagues & 0.866 & 9.578 \\
\hline & KNOW6 & I ask my colleagues about their skills when I want to learn them & 0.696 & 8.281 \\
\hline & KNOW7 & It is important that my colleagues know what I am working on & 0.700 & 8.316 \\
\hline \multirow{5}{*}{ Rewarding } & REW1 & Promotions are in my institution merit-based & 0.907 & - \\
\hline & REW2 & $\begin{array}{l}\text { Employees are rewarded for the provision of high quality } \\
\text { services }\end{array}$ & 0.918 & 21.964 \\
\hline & REW3 & $\begin{array}{l}\text { Promotion in a position depends on how well the employees do } \\
\text { their job }\end{array}$ & 0.898 & 20.719 \\
\hline & REW5 & Creativity and innovation are being rewarded & 0.898 & 20.740 \\
\hline & REW7 & My efforts are rewarded as they should be & 0.811 & 16.460 \\
\hline \multirow{4}{*}{$\begin{array}{l}\text { Innovative } \\
\text { behaviour }\end{array}$} & INNO1 & $\begin{array}{l}\text { At work, I constantly search for new processes and ideas for } \\
\text { performing my job duties }\end{array}$ & 0.725 & 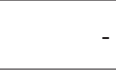 \\
\hline & INNO2 & At work, I promote and share the ideas to other colleagues & 0.816 & 11.441 \\
\hline & INNO3 & At work, I try to implement novel ideas & 0.912 & 12.369 \\
\hline & INNO4 & At work, I develop appropriate plans to implement novel ideas & 0.753 & 10.566 \\
\hline
\end{tabular}


CFA was employed for the assessment of reliability and validity of measures. Overall model fit was tested using the fit indices proposed by (Hair et al., 2014): normed chi-square index, comparative-fit index (CFI), root-mean-square-error (RMSEA), normed-fit index (NFI), and standardized root mean square residual (SRMR). The testing of the model reliability aimed primarily to satisfy some theoretical assumptions and it was measured by the factor of Composite Reliability (CR), which had to be above 0.7 . According to Hair et al., (2014) the convergent validity may be proofed through the factor loadings and the Average Variance Extracted (AVE) in which an appropriate convergence is achieved if these two have values above 0.5 . Discriminant validity was tested by comparing the square root of AVE (which should be higher) with the correlations with all other variables. The reliability and validity were not tested for innovation drivers and networking as the summated aggregated scale was used in their case (Diamantopoulos \& Siguaw, 2000). The results of the CFA are presented in Table 2, and all the measurement models satisfy the assumptions of the fit and reliability.

Table 2: Reliability and validity testing

\begin{tabular}{|l|c|c|c|c|c|c|c|c|c|}
\hline & \multirow{2}{*}{ Item } & \multicolumn{3}{|c|}{ Absolute indicators } & \multicolumn{2}{c|}{$\begin{array}{c}\text { Incremental } \\
\text { indicators }\end{array}$} & \multirow{2}{*}{ CR } & \multirow{2}{*}{ AVE } & \multirow{2}{*}{$\begin{array}{c}\text { SQRT } \\
\text { AVE }\end{array}$} \\
\cline { 3 - 9 } & & $\chi^{2 / d f}$ & RMSEA & SRMR & NFI & CFI & & & - \\
\hline Innovation drivers & 12 & - & - & - & - & - & - & - & - \\
\hline Networking & 9 & - & - & - & - & - & - & - & - \\
\hline Encouragement & 4 & 2.009 & 0.0688 & 0.0102 & 0.994 & 0.997 & 0.918 & 0.739 & 0.860 \\
\hline Empowerment & 4 & 1.548 & 0.0507 & 0.0143 & 0.994 & 0.998 & 0.876 & 0.640 & 0.800 \\
\hline Employee information & 6 & 2.179 & 0.0774 & 0.0290 & 0.980 & 0.989 & 0.886 & 0.567 & 0.753 \\
\hline Rewarding & 5 & 1.701 & 0.0573 & 0.0102 & 0.993 & 0.997 & 0.949 & 0.787 & 0.887 \\
\hline Innovative behaviour & 4 & 2.531 & 0.0848 & 0.0177 & 0.990 & 0.994 & 0.879 & 0.648 & 0.805 \\
\hline
\end{tabular}

Source: Authors'calculation.

The reliability of the models was confirmed as all of them have the CR above 0.7 . Besides, AVE values are above 0.5. Therefore, the assumptions of convergent validity are satisfied for all measurement models. Finally, the square root of AVE values and correlations are presented in Table 3 confirming the discriminant validity.

Table 3: Discriminant validity

\begin{tabular}{|l|r|r|r|r|r|}
\hline & \multicolumn{1}{|c|}{ ENCO } & \multicolumn{1}{c|}{ EMP } & \multicolumn{1}{c|}{ KNOW } & \multicolumn{1}{c|}{ REW } & \multicolumn{1}{c|}{ INNO } \\
\hline ENCO & 0.860 & & & & \\
\hline EMP & 0.535 & 0.800 & & & \\
\hline KNOW & 0.200 & 0.344 & 0.753 & & \\
\hline REW & 0.853 & 0.525 & 0.166 & 0.877 & \\
\hline INNO & 0.263 & 0.447 & 0.580 & 0.206 & 0.805 \\
\hline
\end{tabular}

The square root of AVE values (on the diagonal) are greater than correlations with other constructs presented below 


\subsubsection{Hypotheses testing}

The testing of the hypotheses is conducted in two models. Due to the fact that summated scales were used for DRIV and NETW, these two hypotheses are tested in the first model following Lewis et al., (2018). First, the model fit was assessed following by the path estimations.

Table 4: Hypotheses testing for $\mathrm{H} 1$ and $\mathrm{H} 2$

\begin{tabular}{|c|c|c|c|c|}
\hline & Dependent variable & Independent variable & $\begin{array}{c}\text { Standardized ra- } \\
\text { ting parameter }\end{array}$ & $\begin{array}{l}t-\text { value } \\
\text { one-tailed }\end{array}$ \\
\hline H1 & Innovative behaviour & $\leftarrow$ Innovation drivers & 0.144 & $2.003 * *$ \\
\hline $\mathrm{H} 2$ & Innovative behaviour & $\leftarrow$ Networking & 0.208 & $2.864 * *$ \\
\hline \multicolumn{5}{|c|}{ Chi-Square $=18.147 ; \mathrm{df}=8 ; \mathrm{RMSEA}=0.0771 ; \mathrm{SRMR}=0.0354 ; \mathrm{NFI}=0.966$} \\
\hline
\end{tabular}

All the indicators of the goodness of fit, including the normed $\chi 2 / \mathrm{df}$ of 2.268 , which can be seen on the bottom of Table 4, confirm a very good fit of this model. Furthermore, both hypotheses are supported by the results. Specifically, innovation drivers significantly increase innovative behaviour in public sector institutions $(\beta=0.144$; $\mathrm{t}=2.003 ; \mathrm{p}<0.05)$ and also networking significantly increases innovative behaviour in public sector institutions $(\beta=0.208 ; \mathrm{t}=2.864 ; \mathrm{p}<0.05)$.

Table 5: Hypotheses testing for Model 2

\begin{tabular}{|l|l|c|r|r|}
\hline & Dependent variable & Independent variable & $\begin{array}{c}\text { Standardized } \\
\text { rating } \\
\text { parameter }\end{array}$ & \multicolumn{1}{c|}{$\begin{array}{c}\text { t }- \text { value } \\
\text { one-tailed }\end{array}$} \\
\hline H3 & Innovative behaviour & $\leftarrow$ Encouragement & 0.003 & 0.0228 \\
\hline H4 & Innovative behaviour & $\leftarrow$ Empowerment & 0.391 & $2.994 * * *$ \\
\hline H5 & Innovative behaviour & $\leftarrow$ Empowerment & 0.485 & $5,651^{* * *}$ \\
\hline H6 & Innovative behaviour & $\leftarrow$ Rewarding & -0.156 & -1.148 \\
\hline
\end{tabular}

Chi-Square=354.792; $\mathrm{df}=242 ; \mathrm{RMSEA}=0.0468 ; \mathrm{SRMR}=0.0572 ; \mathrm{NFI}=0.960 ; \mathrm{CFI}=0.985$

$$
* * * p<0.01 ; * * p<0.05 ; * p<0.1
$$

\section{Source: Authors' calculation.}

Based on the results from Table 5, two hypotheses are supported as there is a significant and positive relationship between empowerment and innovative behaviour, and between employee information and innovative behaviour. Empowerment significantly influences innovative behaviour in public sector institutions $(\beta=0.391 ; \mathrm{t}=2.994$; $\mathrm{p}<0.01$ ). In other words, when the employees are satisfied with their involvement at work, when they are authorised and trusted to make the required decisions, and when they have the opportunities for freedom and independence, they will constantly search for new processes and ideas, and develop appropriate plans to implement 
these novel ideas. Moreover, employee information significantly increases innovative behaviour in public sector institutions $(\beta=0.485 ; \mathrm{t}=5.651 ; \mathrm{p}<0.01)$. This means that when the employees are completely informed about what their colleagues know, share new information with their colleagues and ask their colleagues about their skills when they want to learn them, then they will constantly search for new processes and ideas, and develop appropriate plans to implement these novel ideas.

The testing of the fourth hypothesis showed that rewarding negatively influences innovative behaviour in public sector institutions, but this relationship has no statistically significant influence. Moreover, this negative relationship could be a revolt of the employees due to the fact that there is no rewarding system in the PS in FBiH at all. Encouragement does significantly influence innovative behaviour in public sector institutions, but this influence is not statistically significant. Nevertheless, people often confuse encouragement with a situation in which someone is forced and pressured to deliver. In these circumstances, reverse psychology occurs (Kurz et al., 2018), and with the absence of the right leadership skills, the creative process completely stops. There are many examples in which some logical relationship between two variables ends to be not-significant. In this regard, Jung, Chow and $\mathrm{Wu}$ (2003) who also discovered the negative relationship between encouragement and institutional innovation, recommend the identification of a variable that would mediate this relationship, for instance rewarding.

The control variables which are included in both models are age, education, and job position. It is assumed that with the increase of age, innovation decreases, while for the other two control variables a positive relationship to innovation is assumed. The job position has a positive and significant relationship to innovative behaviour in both models $(\beta=0.213, \mathrm{p}<0.01 ; \beta=0.099, \mathrm{p}<0.1)$. This would mean that the higher the job position is, the more innovative an employee is. A justification for this relationship was provided through the qualitative analysis. In fact, the manager and the top-level employees in the public sector in $\mathrm{FBiH}$ are the ones who make decisions and are free to approve new ideas. Every innovation is implemented with their consent, is easily processed, and often they are the ones who take credit also for the ideas coming from the lower-level employees.

\section{CONCLUSION}

This research empirically supported some previous research results regarding the main challenges to PSI. Mongey (2013) recognized that the regulations and the abundance of rules are the main obstacles of public sector innovation; moreover, Francesc (2009) also verified this relation and emphasised that the institutional structure which consists of layers of bureaucracy is the main barrier to innovation. 
Based on the empirical results, this research confirmed some past propositions concerning manager's perception on innovation in which Head (2013) showed that managers perceive innovation as some unnecessary additional work and have an overall resistance to change.

This paper contributes to the understanding of public sector innovation in developing country context as an opportunity to improve the performance of public services, increase their efficiency, and decrease the costs. Several independent variables, which may influence innovative behaviour in the PS, were identified, and six hypotheses were suggested. Namely that, innovation drivers influence innovative behaviour in public sector institutions, and respectively that networking, encouragement, empowerment, employee information, and rewarding influence innovative behaviour in public sector institutions.

When it comes to the determination of the influence of innovation drivers, networking, empowerment and employee information on innovative behaviour, the research confirmed the results of previous studies made by Lewis et al., (2018), Fernandez and Moldogaziev (2012), and Daglio et al., (2014), and showed that there is a significant and positive relationship.

On the other side, no statistically significant relationships were found regarding the influence of encouragement and rewarding on innovative behaviour. People often confuse encouragement with a situation in which someone is forced and pressured to deliver. There are many examples in which some logical relationship between two variables ends to be not-significant. Jung et al., (2003) who also discovered the negative relationship between encouragement and institutional innovation, recommend the identification of a variable that would mediate this relationship, for instance, rewarding.

Moreover, Francesc (2009) found that rewarding enhance PSI, as long as a rewarding system is existant and an integral part of the institutional structure. However, the results point to an interesting phenomenon of differences in perception when it comes to managers and employees of the operational level. Specifically, qualitative analysis showed that managers perceive that introducing an appropriate reward system with performance-sensitive pay would contribute to employee innovation. On the other hand, while managers find rewarding important, the results of hypothesis testing indicate that reward does not affect employees' innovative behavior. The reason for this inconsistency may be found in the complete absence of rewarding in the current setup of the PS system. The lack of rewards causes employee revolt because they do not benefit from their PSI. This practically means that the introduction of rewardings could change the findings, in the line with the findings of Francesc (2009). 
Implications for $\mathrm{FBiH}$ are that the leader and employees are the largest drivers of public sector innovation. The public sector in $\mathrm{FBiH}$ is not innovative enough, and there is a lack of interest in this regard. The institutional culture in the $\mathrm{FBiH}$ is generally closed to novel ideas and processes, and the employees hold a pessimistic attitude toward innovation. The employees are primarily motivated through a personal satisfaction of seeing the result and delivering good work, and the process of innovation includes both bottom-up and the top-down approach. The level of networking is very low and there is almost no communication among different government levels which ultimately causes a lot of the same work being done twice.

This research is of great importance as it has provided a first general picture of the public sector in $\mathrm{FBiH}$ when it comes to innovation and innovative behaviour. The institutions in $\mathrm{FBiH}$ have to, primarily, engage more in digitalisation and appropriate their internal rules in a way which would enable innovation. This is a good starting point through which it can be seen that it is crucial to introduce an innovative institutional structure, a proper rewarding system, and allow the employees to think outside of this regulated box.

\section{REFERENCE LIST}

1. Abukhait, R.M., Bani-Melhem, S. and Zeffane, R., 2019. Empowerment, Knowledge Sharing And Innovative Behaviours: Exploring Gender Differences. International Journal of Innovation Management, 23(01), pp. 1-28.

2. Ahuja, V., Yang, J., and Shankar, R. (2009). Study of ICT adoption for building project management in the Indian construction industry Vanita. Automaton in Construction, 18(4), pp.415-423. https://doi.org/10.1016/j.autcon.2008.10.009

3. Bailey, S. J., 2002. Public sector economics: theory, policy and practice. Basingstroke: Palgrave Macmillan.

4. Bertucci, G., 2005. Innovations in the Public Sector Compendium of Best Practices: Winners of the United Nations Public Service Awards. New York: Department of Economic and Social Affairs.

5. Booyens, I. and Rogerson, C. M. (2017). Networking and learning for tourism innovation: evidence from the Western Cape. Tourism Geographies, 19(3), pp. 340-361.

6. Borins, S. (2001). Encouraging innovation in the public sector. Journal of intellectual capital, 2(3), pp. 310-319.

7. Choi, T., and Chandler, S. M. (2015). Exploration, Exploitation, and Public Sector Innovation: An Organizational Learning Perspective for the Public Sector. Human Service Organizations Management, Leadership and Governance, 39(2), pp. 139-151. https://doi.org/10.1080/23303131.2015.1011762 
8. Cinar, E., Trott, P. and Simms, C. (2019). A systematic review of barriers to public sector innovation process. Public Management Review, 21(2), pp. 264-290.

9. Coveney, B. C. H. (2008). Assessing the organisational climate for creativity in a UK Public Library Service: a case study. Library and Information Research, 32(102), pp. 38-56. https://doi.org/10.29173/lirg83

10. Daglio, M., Gerson D. and Kitchen, H., 2014. Building Organisational Capacity for Public Sector Innovation. Paris: OECD.

11. Diamantopoulos, A., and Siguaw, J. A., 2000. Introducing LISREL: A guide for the uninitiated. Sage.

12. Fernandez, S. and Moldogaziev, T. (2012). Using employee empowerment to encourage innovative behavior in the public sector. Journal of Public Administration Research and Theory, 23(1), pp. 155-187.

13. Francesc, P., 2009. Systemic Innovation in Vet. Paris: OECD Centre for Educational Research and Innovation Governing Board.

14. Hair, J. F., Black, W. C., Babin, B. J., and Anderson, R. E. (2014). Multivariate Data Analysis. In Prentice-Hall, Inc (Seventh ed). https://doi.org/10.1038/259433b0

15. Head, G., 2013. Creating an Innovative Public Sector. New South Wales: Public Service Commission.

16. Hurley, R. F., and Hult, G. T. M. (1998). Innovation, market orientation, and organisational learning: An integration and empirical examination. Journal of Marketing, Vol. 62, pp. 42-54. https://doi.org/10.2307/1251742

17. Jung, D. I., Chow, C. and Wu, A. (2003). The role of transformational leadership in enhancing organizational innovation: Hypotheses and some preliminary findings. The leadership quarterly, 14(4-5), pp. 525-544.

18. Kasabov, E. (2016). Unknown, surprising, and economically significant: The realities of electronic word of mouth in Chinese social networking sites. Journal of Business Research, 69(2), pp. 642-652. https://doi.org/10.1016/j. jbusres.2015.08.036

19. Keping, Y. (2018). Governance and Good Governance: A New Framework for Political Analysis. Fudan Journal of the Humanities and Social Sciences, 11(1), pp. $1-8$.

20. Koch, P. and Hauknes, J., 2005. On innovation in the public sector-today and beyond. Oslo: Publin. 
21. Kurz, V., Hüsig, S. and Dowling, M. (2018). What drives different employee types of innovative behaviour? Development and test of an integrative model of employee driven innovation in German firms. International Journal of Entrepreneurship and Innovation Management, 22(4-5), pp. 397-426.

22. Lewis, J. M., Ricard, L. M. and Klijn, E. H. (2018). How innovation drivers, networking and leadership shape public sector innovation capacity. International Review of Administrative Sciences, 84(2), pp. 288-307.

23. Mongey, O., 2013. Innovation in the Irish public sector. Sligo: Institute of Technology.

24. Nusair, N., Ababneh, R. and Kyung Bae, Y. (2012). The impact of transformational leadership style on innovation as perceived by public employees in Jordan. International Journal of Commerce and Management, 22(3), pp. 182-201.

25. Organization for Economic Cooperation and Development., 2017. Fostering Innovation in the Public Sector. Paris: OECD Publishing.

26. Schot, J. and Steinmueller, W. E. (2018). Three frames for innovation policy: $R \& D$, systems of innovation and transformative change. Research Policy, 47(9), pp. 1554-1567.https://doi.org/10.1016/j.respol.2018.08.011

27. Singh, M. and Sarkar, A. (2019). Role of psychological empowerment in the relationship between structural empowerment and innovative behaviour. Management Research Review, 42(4), pp. 521-538.

28. Sørensen, E. and Torfing, J. (2011). Enhancing collaborative innovation in the public sector. Administration \& Society, 43(8), pp. 842-868.

29. Taylor, S. P. (2018). Innovation in the public sector: dimensions, processes, barriers and developing a fostering framework. International Journal of Research Science \& Management, 5(1), pp. 28-37.

30. Thornton, G., 2012. Innovation in Government: Getting our mojo back. New Zealand: Grant Thornton International Ltd.

31. Wisdom, J. P., Ho, K., and Chor, B. (2014). Innovation Adoption: A Review of Theories and Constructs. pp. 480-502. https://doi.org/10.1007/s10488-0130486-4

32. Zsidisin, G. A., Melnyk, S. A., and Ragatz, G. L. (2005). An institutional theory perspective of business continuity planning for purchasing and supply management. International Journal of Production Research, 43(16), pp. 3401-3420. https://doi.org/10.1080/00207540500095613 
Zlatko Lagumdžija

Lamija Krndžija

Lejla Turulja

\section{INOVACIJE U INSTITUCIJAMA JAVNOG SEKTORA U FEDERACIJI BOSNE I HERCEGOVINE}

\section{SAŽETAK}

Inovacija je postala potreba da se prevladaju izazovna vremena u brzom svijetu koji se mijenja. Svjetska paradigma se pomiče prema održivom razvoju i zajedničkim vrijednostima. Iako su brojne koristi od inoviranja javnog sektora (PS) prepoznate širom svijeta, koncept inovacije u javnom sektoru (PSI) još uvijek je nov za Bosnu $i$ Hercegovinu. Složena i slojevita struktura Federacije Bosne i Hercegovine (FBiH) $i$ njezinog PS-a zauvijek stoji na putu svakog većeg napretka.

Svrha ovog rada je doprinijeti razvoju PSI u FBiH u cilju poboljšanja performansi javnih usluga, povećanja njihove efikasnosti $i$ smanjenja troškova. Istraživanje je završeno primjenom mješovitog metoda kako bi se analizirao koncept inovacije u PS. Primarni podaci prikupljeni su polu strukturiranim intervjuima s upravom $i$ anketom sa zatvorenim pitanjima koju su popunili zaposlenici Institucija javnog sektora u FBiH. Za ispitivanje hipoteza korištena je metoda modeliranja strukturalnih jednačina.

Dio ovog rada analizira glavne pokretače PSI-ja i izazove. Rezultati pokazuju da su glavne prepreke PSI-u institucionalni sistem i propisi u FBiH. S druge strane, menadžer i zaposlenici smatraju se najvećim pokretačima inovacija u javnom sektoru u FBiH. Ovaj članak završava s nekoliko preporuka o tome kako prevazići glavne prepreke u javnom sektoru u FBiH.

Ključne riječi: Inovacijsko upravljanje, istraživanje i razvoj, poticaji za inovacije, e-uprava, institucionalna kultura.

JEL: $O 38, O 32, O 31, H 11, H 41$ 